Syntax Literate: Jurnal Ilmiah Indonesia p-ISSN: 2541-0849 e-ISSN : 2548-1398

Vol. 6, Spesial Issue No. 1, November 2021

\title{
REPRESENTASI ANIES DAN GANJAR PADA BURSA CALON PRESIDEN INDONESIA 2024 DALAM BERITA ONLINE OKEZONE.COM
}

\section{Nuri Hermawan}

Universitas Airlangga, Indonesia

Email: nuri-hermawan@staf.unair.ac.id

\begin{abstract}
Abstrak
Penelitian ini bertujuan untuk mengungkap representasi nama Anies Baswedan dan Ganjar Pranowo sebagai tokoh yang sering disebut-sebut dan unggul dalam beberapa survei sebagai calon Presiden Indonesia tahun 2024. Menggunakan sumber dari data bahasa yang muncul pada berita dalam jaringan okezone.com, penelitian ini menggunakan metode analisis wacana kritis dengan bantuan linguistik korpus atau Corpus-Assisted Critical Discourse Analysis. Pendekatan pada penelitian ini menggunakan pendekatan corpus-driven dan corpus-based yang bertujuan untuk membantu pemilihan sumber data, pengumpulan data, dan identifikasi topik berita yang menggambarkan bagaimana dua sosok kandidat terkuat yang muncul pada bursa Pilpres 2024. Selanjutnya, teknik linguistik korpus yang digunakan pada penelitian ini bertujuan untuk menganalisis kompilasi korpus yang meliputi frekuensi, kata kunci, kelompok, kolokasi, dan konkordansi. Analisis kritis terhadap data diungkapkan dengan melihat representasi dua nama tokoh yang muncul dan sengaja diciptakan oleh media okezone.com. Representasi kandidat Pilpres 2024 tersebut dilakukan dengan menggunakan tipe-tipe wacana yang dilatarbelakangi arah penggiringan opini pada media okezone.com. Dari representasi dua nama kandidat yang sering muncul ditarik kesimpulan bahwa keduanya merupakan sosok yang pantas maju pada kontestasi Pilpres 2024. Namun, sosok Anies digambarkan sebagai figur yang maju dengan jalan yang tenang, sedang Ganjar digambarkan figur yang punya ambisi dan sudah memetakan langkah menuju Pilpres 2024.
\end{abstract}

Kata Kunci: representasi; pilpres 2024; analisis wacana kritis; CACDA

\section{Abstract}

This study aims to reveal the representation of the names of Anies Baswedan and Ganjar Pranowo as figures who are often mentioned and excel in several surveys as candidates for President of Indonesia in 2024. Using the source of language data that appears on news in the okezone.com network, this study uses the method critical discourse analysis with the help of corpus linguistics or Corpus-Assisted Critical Discourse Analysis. The approach in this study uses a corpus-driven and corpus-based approach which aims to assist in selecting data sources, collecting data, and identifying news topics that describe how the two strongest candidate figures emerged in the 2024 presidential election. Furthermore, the corpus linguistic technique used in This study aims to analyze the compilation of the corpus which includes frequency, keywords, groups, collocations, and 
concordance. Critical analysis of the data is revealed by looking at the representations of two names of characters that appeared and were deliberately created by okezone.com media. The representation of the candidates for the 2024 presidential election was carried out using types of discourse that were motivated by the direction of leading opinion on the media okezone.com. From the representation of the two candidate names that often appear, it can be concluded that both of them are worthy figures in the 2024 presidential election contestation. However, Anies is described as a figure who advances with a calm path, while Ganjar is described as a figure who has ambition and has already mapped out steps towards the 2024 presidential election.

Keywords: representation; the 2024 presidential election; critical discourse analysis; CACDA

Received: 2021-10-20; Accepted: 2021-11-05; Published: 2021-11-18

\section{Pendahuluan}

Sebagai salah satu negara yang menganut sistem demokrasi, pemilihan presiden merupakan peristiwa politik yang sangat penting di Indonesia. Iklim demokrasi dan bentuk pemerintahan presidensial menjadikan presiden sebagai pemangku kekuasaan tertinggi dalam menentukan beragam kebijakan di pemerintahan. Tercatat, sejak runtuhnya orde baru dan bergulirnya reformasi tahun 1998, pemilihan presiden di Indonesia terjadi 5 tahun sekali menjadi semakin menarik untuk diamati. Mengingat, dengan atmosfer politik yang lebih demokratis, pemilihan presiden pun dilakukan secara langsung oleh rakyat. Tidak jarang pemilihan presiden yang berlangsung sangat erat pengaruhnya dengan peran media sebagai penyampai informasi. Terlebih di era keterbukaan seperti saat ini, media memegang peranan penting dalam menggiring opini publik untuk menentukan siapa yang tepat menjadi pemimpinnya selama lima tahun mendatang.

Tahun 2024 meski terbilang masih lama, namun aura kontestasi akbar Pemilihan Presiden (pilpres) yang bakal berlangsung pada tahun tersebut sudah terasa mulai saat ini. Bahkan usai pilpres tahun 2019 lalu, media sudah dihebohkan dengan nama-nama calon presiden yang bakal melanjutkan kepemimpinan Presiden Joko Widodo. Salah satu media itu adalah laman berita dalam jaringan okezone.com. Dari sumber https://management.okezone.com/ dijelaskan bahwa okezone.com resmi diluncurkan (Commercial Launch) sebagai portal berita pada 1 Maret 2007. Lahirnya okezone.com menjadi cikal-bakal bisnis online pertama milik PT Media Nusantara Citra Tbk (MNC), sebuah perusahan media terintegrasi yang terbesar di Indonesia dan Asia Tenggara. Bahkan, mulai Juni 2019, okezone.com menduduki peringkat ke-2 untuk kategori portal berita terpopuler di Indonesia. Prestasi ini tercipta karena semakin banyak pengunjung situs yang mengakses okezone.com setiap harinya. Untuk itu, sangat menarik jika penelitian ini mengulas seberapa besar penggambaran calon presiden yang digambarkan oleh media tersebut. Sebab itulah penelitian ini memiliki tujuan untuk mengetahui bagaimana perspektif media dalam jaringan okezone.com terhadap kandidat presiden 
2024. Pemilihan media daring sebagai sumber data karena penyebarannya yang sangat luas. Tidak hanya itu media daring juga memungkinkan penulis melakukan penelitian terhadap teks yang jumlahnya sangat banyak dengan metode analisis data secara ekstensif. Bahkan, ada lima puluh ribu kata lebih yang berhasil dihimpun dari berita yang muncul terkait bursa nama calon presiden 2024 dari tahun 2019 hingga saat ini. Selanjutnya, dengan analisis yang ekstensif, pada penelitian ini dapat ditemukan analisis data dengan cakupan yang sangat luas tanpa harus menganalisis data tersebut satu per satu.

Salah satu metode yang dapat menganalisis data dengan cakupan yang luas adalah linguistik korpus (corpus linguistics). Mengutip pernyataan (Williams, 2006) menjelaskan bahwa Linguistik korpus merupakan metode yang dapat menganalisis data dalam jumlah yang besar dengan menggunakan teknologi komputer sebagai alat bantunya. Namun, untuk melakukan analisis selanjutnya terhadap data secara mendalam, metode ini saja tidak cukup. Oleh sebab itu, diperlukan metode lain yang dapat menganalisis data secara mendalam. Salah satu metode analisis yang mendalam dan bisa digunakan pada penelitian ini adalah analisis wacana dan analisis wacana kritis. Metode analisis wacana kritis menggunakan data linguistik dengan menempatkan bahasa sebagai produk dari dunia sosial atau praktik wacana yang terjadi di ranah sosial.

Selanjutnya, dalam penelitian ini juga menggunakan metode gabungan, salah satu metode gabungan yang dapat digunakan untuk menganalisis data dengan jumlah yang banyak dan dengan kedalaman analisis yaitu Corpus Assisted Critical Discourse Analysis (CACDA). Prinsip dari metode ini adalah membandingkan fitur-fitur yang ada di dalam teks, tipe-tipe wacana tertentu, dan mengintegrasikannya ke dalam teknik analisis yang dikembangkan dengan korpus linguistik. Selanjutnya, pada tahap analisis difokuskan dengan menggunakan analisis wacana kritis atau AWK. Pada tahap ini katakata yang telah dianalisis dalam korpus linguistik menjadi bahan penting untuk melihat seberapa jauh bahasa digunakan dan masuk dalam ruang konteks sosial dan politik yang membentuk teks serta mensiratkan dominasi ideologi tertentu.

Lain halnya dengan prinsip CACDA, secara umum menjelaskan bahwa CACDA bekerja dengan menggabungkan dua pendekatan yaitu kuantitatif dan kualitatif. Pendekatan kuantitatif dalam penelitian ini hadir melalui metode korpus yang di dalamnya akan digunakan untuk menganalisis data dalam jumlah besar. Data dalam jumlah besar ini, selanjutnya akan dianalisis dengan cara menghitung frekuensi kemunculan dan kuantitas kata-kata yang hadir di dalam konstruksi tertentu. Data kuantitatif ini sangat penting untuk membuktikan sebuah makna, konstruksi realitas yang dibangun oleh wacana yang dapat dibuktikan secara kuantitas. Hal tersebut tentu untuk menghindari pendekatan yang bersifat intuitif atau berdasarkan perasaan dan anggapan penulis saja. Selanjutnya, pendekatan kualitatif pada riset ini digunakan untuk menganalisis data kuantitatif tersebut. Pendekatan ini dapat digunakan untuk memperoleh kedalaman pemahaman mengenai makna, konstruksi realitas, dan lain-lain secara kritis serta mendalam. 
Mengutip pernyataan (Hardt-Mautner, 2009) dan (Baker, 2010) bahwa dengan analisis data yang luas dan sekaligus mendalam, penelitian akan mendapatkan cara bagaimana sebuah wacana dibangun melalui konstruksi kebahasaan. Untuk itulah, keuntungan yang dapat diperoleh dari metode CACDA penelitian dapat menganalisis data secara ekstensif sekaligus mendalam. Sebuah wacana yang muncul dalam pemberitaan akan memiliki makna tertentu, sesuai dengan cara wacana tersebut dikonstruksi dalam pemberitaan yang terus-menerus. Selain hal-hal itu, dalam penelitian kita dapat melihat bagaimana sebuah wacana bermakna tertentu berdasarkan data korpus yang banyak.

Pemberitaan media yang mengulas tentang tokoh politik tertentu dan beberapa hal yang telah lakukan dapat dianalisis dengan data korpus yang luas dan analisis tingkat berikutnya secara mendalam. Misalnya, pemberitaan tentang calon presiden 2024 yang sudah beredar banyak pada media, dalam data yang sangat luas akan menghasilkan kecenderungan ideologis tertentu dari media yang memberitakannya atau kecenderungan representasi tertentu tentang sosok tersebut. Ideologi dalam hal ini dapat dipahami sebagai sebuah cara media untuk menggiring seseorang atau sekelompok orang atau publik melihat seseorang, kelompok lain, atau dunianya.

Menurut (Adolphs, 2006) menjelaskan bahwa korpus linguistik sering didiskusikan sebagai linguistik yang berlawanan dengan linguistik Chomskyan, yang terfokus pada kompetensi bahasa dan intuisi penutur asli sebagai basis untuk teori linguistiknya. Tidak hanya itu, (Adolphs, 2006) juga menjelaskan ada beberapa keuntungan yang didapatkan dengan menganalisis teks elektronik. Pertama, penggunaan analisis teks elektronik merupakan proses yang dapat direplikasi. Kedua, analisis teks elektronik menghindarkan peneliti dari analisis yang intuitif. Ketiga, analisis teks elektronik memungkinkan peneliti untuk memanipulasi data bahasa di dalam banyak cara untuk disesuaikan dengan tujuan penelitian. Keempat, sekali menyortir data dengan cara yang dapat diakses, kita dapat melakukan analisis lebih lanjut terhadap data tersebut. Kelima, analisis data elektronik dapat dilakukan pada level yang berbeda-beda. Keenam, analisis teks elektronik dapat dilakukan secara kuantitatif dan kualitatif.

Dari paparan pengantar di atas, salah satu hal yang menarik untuk dianalisis dengan menggunakan metode ini adalah pemberitaan tentang Anies Baswedan dan Ganjar Pranowo yang namanya kerap masuk pada beberapa lembaga survei untuk bisa memenangkan Pilpres 2024. Kecenderungan bahasa yang muncul di dalam pemberitaan tentang kedua sosok akan memunculkan dengan menunjukkan sebuah pola makna tertentu di dalam analisis CACDA. Melalui analisis ini akan dapat dilihat bagaimana sosok Anies dan Ganjar tersebut direpresentasikan, kata-kata apa saja yang paling sering muncul, medan makna apa yang muncul dengan konstruksi bahasa yang ada, dan seperti apa arah media menggiring opini publik. 


\section{Metode Penelitian}

Ada dua metode gabungan yang digunakan pada penelitian ini, yaitu analisis wacana kritis (CDA) dan linguistik korpus. Patington dan Haarman (2004) menjelaskan bahwa metode penelitian ini dikenal sebagai Corpus-Assisted Critical Discourse Analysis atau CACDA. Pada dasarnya, seperti yang dijelaskan (Baker, 2010) metode ini menggunakan pendekatan kualitatif deskriptif untuk menganalisis data. Selanjutnya, pada tataran AWK metode penelitian ini mencakup tiga struktur sebagaimana dijelaskan oleh (N Fairclough, 1995) yaitu mikro, meso, dan makro. Pada struktur mikro akan difokuskan pada pengolahan teks elektronik berupa leksikal dan koherensi dengan menggunakan metode korpus linguistik. Media dari okezone.com akan menjadi kajian pada tataran meso dan makro karena berhubungan dengan produksi, distribusi, dan konsumsi berita serta ideologi dari media tersebut. Kemudian, sebagai kajian dalam tataran makro, konteks peristiwa yang menjadi topik utama pada teks berita yang dihimpun sejak isu nama-nama tokoh yang masuk bursa Pilpres 2024 mulai mencuat. Yakni, tercatat dalam periode 2019 pertengahan hingga saat ini.

Menurut (Hardt-Mautner, 2009), dan (Norman Fairclough, 2013) menjelaskan beberapa langkah yang dapat diikuti oleh para peneliti dalam studi analisis CACDA. Langkah pertama adalah merancang pertanyaan penelitian. Langkah berikutnya adalah membangun dan menyusun korpus yang sesuai. Pada langkah ini mencakup prosedur yang berbeda, seperti mendapatkan hak cipta teks, dan mengatur korpus. Langkah ketiga adalah menginvestigasi konteks dengan membaca sejarah, politik, dan budaya dari topik yang sedang diteliti. Pada langkah ini juga mencakup surfing literatur yang ada dan membaca beberapa studi yang memanfaatkan kedua metode tersebut. Selanjutnya adalah menemukan paket perangkat lunak CL yang sesuai untuk menjalankan korpus. Langkah kelima adalah membuat daftar frekuensi dan kata kunci, memeriksa frekuensi relatif terhadap topik yang dibahas, serta kata kunci statistik yang signifikan dan terkait langsung dengan topik ini. Kemudian, memeriksa daftar kolokasi dan gugus untuk beberapa pola leksikal yang telah ditemukan pada langkah sebelumnya. Langkah berikutnya adalah membuat analisis konkordansi kualitatif untuk beberapa pola leksikal yang ditemukan pada langkah sebelumnya. Setelah itu, daftar yang dibuat pada langkah 5-7 diamati dan dipelajari untuk menemukan item yang tampaknya berkelompok menjadi seperangkat semantik. Selanjutnya, data dianalisis dalam konteks yang lebih luas berdasarkan makna leksikal dan jenis koherensinya.

\section{Hasil dan Pembahasan}

Pada tahap analisis teks, penelitian ini menggunakan beberapa operasi software linguistik korpus yang relevan, antara lain wordlist (daftar kata), frequence (frekuensi), kolokasi, dan konkordansi. Melalui aplikasi AntCont, didapat salah satu hasilnya seperti yang ditampilkan dalam gambar tangkapan layar seperti berikut: 


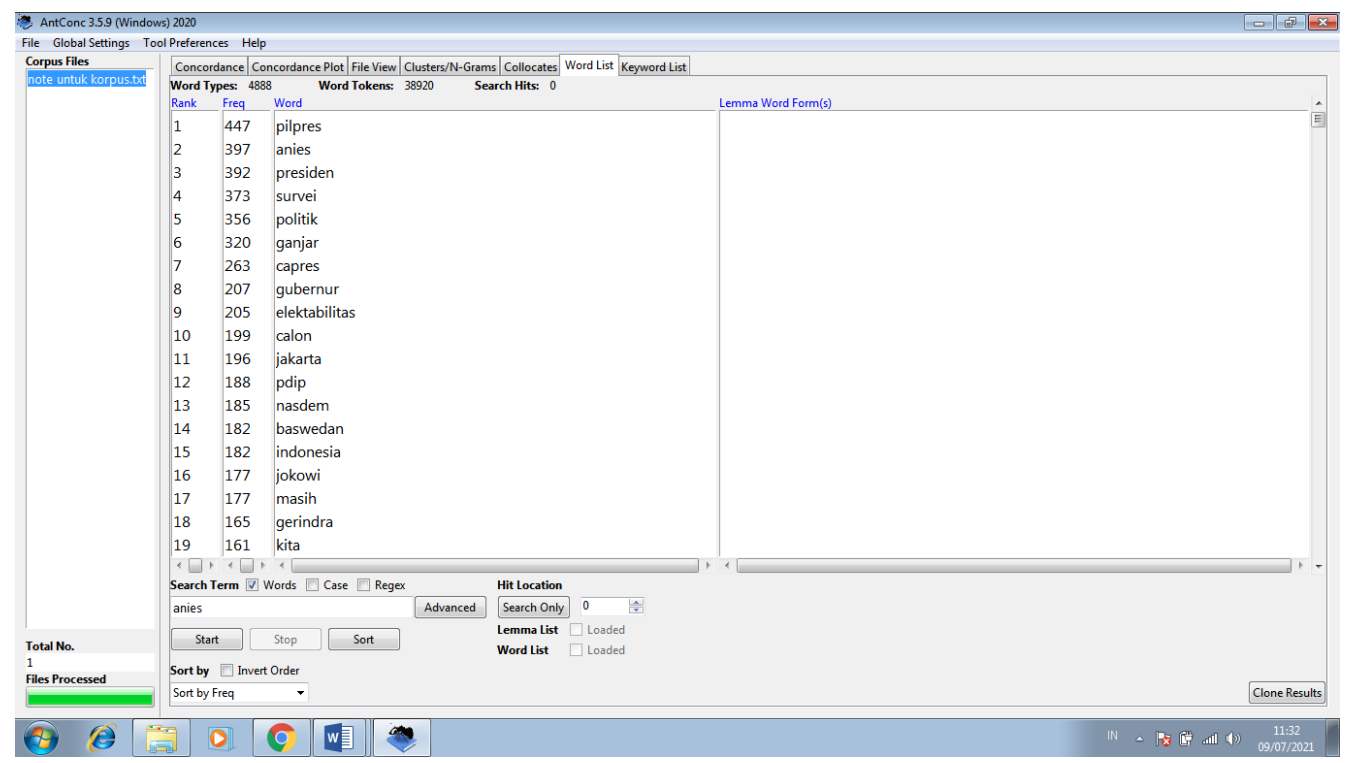

Tampak pada gambar tangkapan layar di atas kata yang memiliki makna leksikal dengan frekuensi yang tinggi atau di atas tiga ratus adalah pilpres (447), anies (397), presiden (392), survei (373), politik (356), dan ganjar (320). Dari data tersebut nampak nama Anies lebih unggul dibandingkan dengan nama Ganjar. Meski selisih tidak begitu banyak, pada data tersebut bisa ditarik beberapa kesimpulan bahwa secara tidak langsung okezone.com memberikan ruang lebih besar kepada sosok Gubernur DKI Jakarta ketimbang Gubernur Jawa Tengah. Namun, kondisi Anies sebagai yang berada pada pusat pemerintahan negara ini dan dengan segala banyak dinamika isu yang sering muncul dipermukaan publik juga menjadi alasan tersendiri nama Anies lebih banyak muncul dibandingkan Ganjar yang notabene memimpin wilayah di daerah. Dari frekuensi ini belum bisa disimpulkan ke arah mana media okezone.com menggiring opini publik, mengingat kondisi keduanya berada pada tataran yang tidak sama.

Selanjutnya, penelusuran lebih jauh untuk mendapatkan konteks yang lebih luas dengan menggunakan konkordansi yang diperluas (extended concordance) ditemukan bahwa penggambaran kedua sosok tersebut dengan leksikon yang berkolokasi dengan kedua nama tersebut kemudian diklasifikasi berdasarkan prosodi semantiknya (positif, negatif, dan netral). Semantic Prosody atau Prosodi Semantik, juga bagian dari prosodi wacana. Perannya menggambarkan cara di mana kata-kata tertentu yang tampaknya netral dapat dipersepsikan dengan asosiasi positif atau negatif melalui kemunculan yang sering dengan kolokasi tertentu. Diciptakan dalam analogi dengan prosodi linguistik, dipopulerkan oleh Bill Louw. Berikut adalah tangkapan layar dari penggambaran kedua sosok tersebut dengan leksikon yang berkolokasi. 

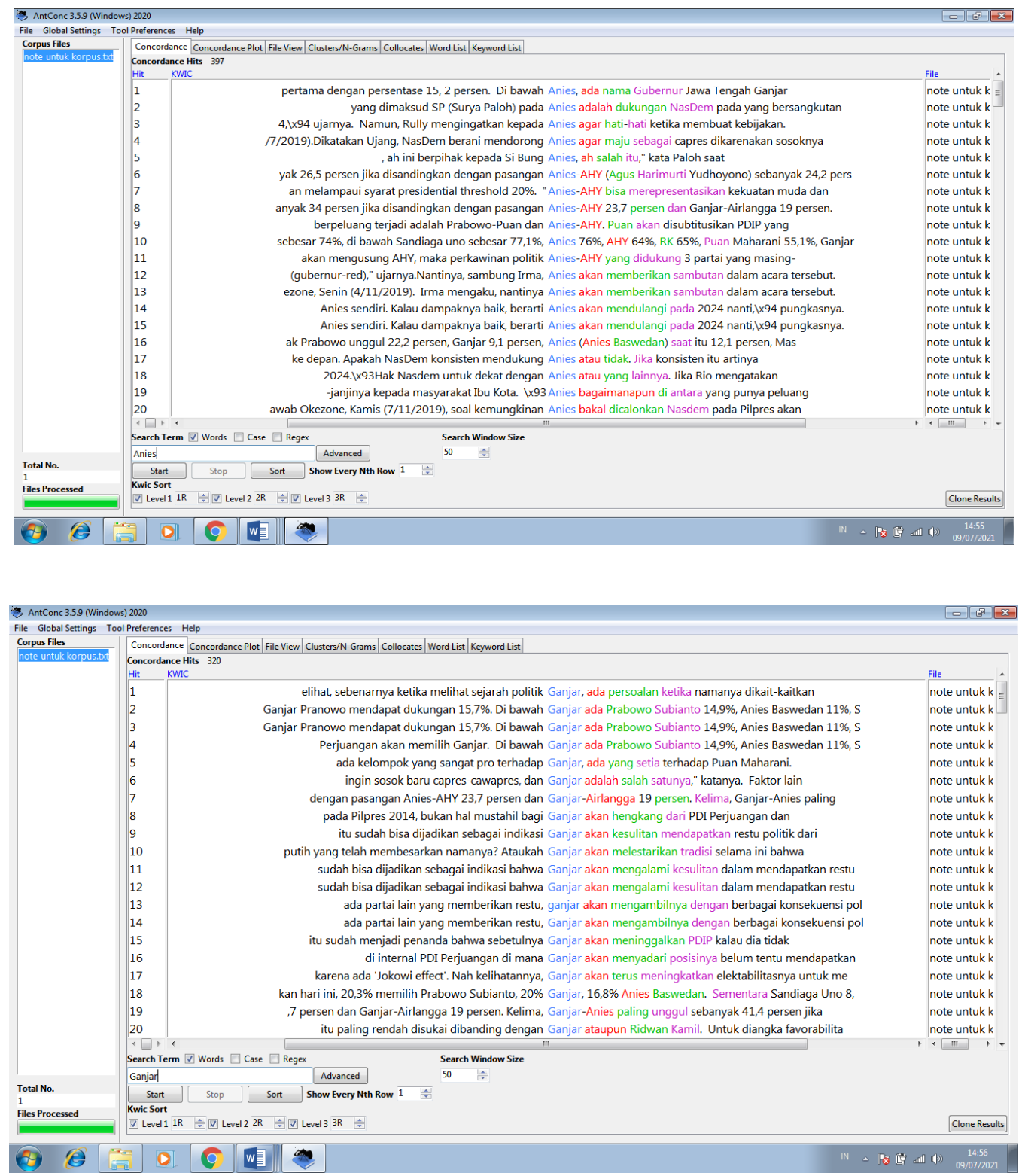

Setelah setiap korpus dikonfirmasi dengan metadata yang berupa topik berita, ditemukan persentase representasi antara Anies dan Ganjar yang kurang lebih sama. Baik dari sisi pemberitaan negatif, positif, maupun netral. Namun, ada yang menarik saat identifikasi representasi keduanya. Meski digambarkan sebagai sosok yang sangat tepat untuk maju pada kontestasi Pipres 2024, okezone.com menggambarkan sosok Anies dengan gaya yang lebih cenderung tenang. Meski Anies punya arah untuk maju pada Pilpres 2024, Anies digambarkan sebagai sosok yang realistis, meyakinkan, figur yang kuat, ahli, kemampuan yang cakap, fokus, layak, potensial, sosok yang leading, intelektual, fokus bekerja, dan diperhitungkan. Lain halnya dengan Ganjar, meski ia juga dinilai tepat sebagai tokoh yang masuk pada bursa Pilpres 2024, Ganjar digambarkan sebagai sosok yang punya ambisi, berani, kelewatan (kemajon), berkarakter, lues, tak tahu diri, terlalu genit, dan mendahului. Penggambaran keduanya tentu tidak bisa lepas dari posisi keduanya saat ini. Anies sebagai figur yang berasal dari 
lingkungan non partai sedikit punya leluasa untuk melanggengkan langkahnya tanpa ada hambatan dari internal. Sedangkan Ganjar, sebagai kader partai dia harus memiliki mekanisme yang tentu dalam beberapa kesempatan tidak menguntungkan posisi Ganjar saat ini.

Analisis kualitatif terhadap hasil konkordansi yang diperluas berdasarkan prosodi semantik leksikon dan koherensi yang menggambarkan kedua sosok pada setiap topik beritanya menunjukkan beberapa karakter yang digunakan okezone.com dalam pemberitaannya. Analisis kritis menunjukkan bahwa Anies sebagai tokoh yang digadang-gadang maju pada Pilpres 2024 nampak tenang, mulus, dan tanpa ada hambatan. Hal itu, tidak terlepas dari posisi Anies saat ini yang tidak terlibat pada partai besar manapun. Sedangkan Ganjar, sebagai sosok yang digambarkan juga layak maju pada Pilpres 2024 dengan segala bentuk hambatan dan banyak kritikan. Kata mendahului dan tak tahu diri sudah cukup mewakili bagaimana sosok Ganjar sebagai kader salah satu partai terbesar di republik ini harus mengikuti mekanisme yang sudah ditentukan partai.

Melalui analisis meso dan makro ditemukan bahwa representasi Anies dan Ganjar tidak bisa lepas dari prinsip ideologi okezone.com sendiri. Secara latar belakang, sebagai anak usaha dari MNC Group milik salah satu pengusaha ternama di Indonesia yang juga sempat mendirikan partai dan ikut kontestasi pemilu pada tahun 2019, tentu memberikan gambaran tersendiri pada kontestasi pemilu 2024 mendatang. Itu sebabnya gambaran netral masih mendominasi pemberitaan yang mengulas sosok kedua figur tersebut (Stefanowitsch \& Gries, 2003). Hal itu mengingat, partai yang dimiliki oleh pemilik MNC Group tidak ikut pada lingkaran penguasa saat ini dan hal tersebut menjadi sebuah kemungkinan bahwa tidak adanya dampak yang signifikan terhadap kepentingan media meski kedua figur nanti apakah akan benar-benar maju atau justru ada sosok baru yang saat ini belum terekam media sama sekali.

\section{Kesimpulan}

Pada penelitian ini dapat ditarik kesimpulan bahwa analisis wacana kritis yang dibantu dengan linguistik korpus dapat mengungkapkan representasi Anies dan Ganjar sebagai sosok kandidat yang masuk pada bursa Pilpres 2024 dalam media okezone.com. Analisis kuantitatif dan kualitatif yang difasilitasi linguistik korpus menunjukkan kedua tokoh tersebut dilakukan dengan menggunakan tipe-tipe wacana yang dilatarbelakangi posisi media yang dimiliki oleh pengusaha yang tidak terlibat pada lingkaran pemerintahan. Dari penelitian ini tampak bahwa penggunaan CACDA merupakan sebuah metode yang perlu dipertimbangkan untuk mendapatkan hasil penelitian yang lebih valid karena dapat lebih merepresentasikan realitas. Penelitian tentang representasi figur dan tokoh penting seperti kepala negara dapat dilakukan dengan media yang lebih beragam dan tidak hanya pada satu sumber saja untuk mendapatkan temuan yang lebih menarik karena data yang digunakan akan lebih besar. 


\section{BIBLIOGRAFI}

Adolphs, Svenja. (2006). Introducing electronic text analysis: A practical guide for language and literary studies. Routledge. Google Scholar

Baker, Paul. (2010). Sociolinguistics and corpus linguistics. Edinburgh University Press. Google Scholar

Fairclough, N. (1995). Media Discourse. London: Edward Arnold Garrett (Eds.). Approaches to Media Discourse. Oxford: Blackwell. Google Scholar

Fairclough, Norman. (2013). Critical discourse analysis: The critical study of language. Routledge. Google Scholar

Hardt-Mautner, Gerlinde. (2009). "Only Connect". Critical Discourse Analysis and Corpus Linguistics. UCREL Lancaster. Google Scholar

Stefanowitsch, Anatol, \& Gries, Stefan Th. (2003). Collostructions: Investigating the interaction of words and constructions. International Journal of Corpus Linguistics, 8(2), 209-243. Google Scholar

Williams, Geoffrey. (2006). Michael Hoey. Lexical Priming: A New Theory of Words and Language. London: Routledge. 2005. xiii+ 202 pages. ISBN 0-415-32863-2. International Journal of Lexicography, 19(3), 327-335. Google Scholar

\section{Copyright holder:}

Nuri Hermawan (2021)

First publication right:

Syntax Literate: Jurnal Ilmiah Indonesia

This article is licensed under: 